\title{
The Influence of Intellectual Capital to Market Value with Return on Assets as Intervening Variable
}

\author{
Marcellina Yovita \\ Faculty of Economics and Business \\ Universitas Padjadjaran \\ Gia Kardina Prima Amrania \\ Faculty of Economics and Business \\ Universitas Padjadjaran
}

\begin{abstract}
This research using leverage as the control variable to measure the relationship between IC and ROA and IC - market value indirect relationship. IC was measured with VAIC $^{\mathrm{TM}}$ method; ROA was used as the measurement that represented profitability. The market value was measured with price-to-book value (PBV) ratio. The research was conducted on 215 companies in Indonesia Stock Exchange as samples in 2014 from six industry sectors those included in high-IC intensive classification by GICS. Analysis descriptive method was used on secondary data. MS Excel and EViews were used to process the data. F-test and t-test were used to test the hypothesis on 5\%-significance. The results showed that IC influences ROA significantly; simultaneously and partially. IC also influences market value directly and indirectly through ROA, though the indirect influence is greater.
\end{abstract}

Keywords: Intellectual capital; Value Added Intellectual Coefficient; ROA; Market value.

\section{Introduction}

The sustainable business process doesn't only need economy resources, but also the ability to manage the resources. Intellectual capital management is meant to make a company more effective and efficient in achieving its target. Completing or even exceeding target makes good company's public image. Good branding stimulates the market value of a company. Higher market value accelerates business process' cycle. These days, the intellectual material knowledge, information, intellectual property, experience that can be put to use to create wealth called intellectual capital (IC) (Bontis, 1998).
IC consists of three components; human capital, structural capital, and capital employed. IC, the rising star of industrial competition strategy, has become an essential thing for management to sustain the business and increase competitiveness on upcoming free-trade. Moreover, the optimism of the Indonesian stock market opens an extensive chance for a company to collect more capital to develop and expand its business. Because of that, tests on IC's effect on market value to return on assets as variable intervening are needed.

Tests were conducted with all listed companies in Indonesia Stock Exchange (IDX) that completed the sampling 
requirements. This study got 215 samples consisting of six sectors of industry; infrastructure, utility and transportation, property and real estate, trading, and service, consumer goods, miscellaneous, and finance. This paper consists of several sections. In the following part will talk about previous research that concern about IC and its influence on the company. Next section will explain the hypothesis that will be tested in this research and then followed by the result. Then topped with, elaboration of the processed data and conclusions on the hypotheses that have been made

\section{Literature Review and Hypothesis}

Free trade is becoming wider regionally and even globally these days, it makes every individual need to improve themselves with competence and knowledge so they can give added value to the companies. It's supported by the fact that companies have changed their business pattern from labor-based into knowledgebased, with knowledge as the main character to survive (Sawarjuwono, 2003). This knowledge will develop the companies in line with technology development, without shrinkage or amortization.

This situation forces the company to be ready with a better quality of knowledgemanagement. In the past, capital management focused more on intangible assets than intangible assets (i.e., knowledge). Whereas in knowledge-based business, the survival of the company is more supported by its intangible than tangible assets. Sangkala (2007) stated that the capital composition of the company had been inverting for eight decades; 1920 with $70 \%$ tangible assets and 30\% intangible assets capital composition, started to change in 1978 with $63 \%$ and $37 \%$ composition, inverted in 1988 with $45 \%$ and 55\% composition, continued in 1998 became $30 \%$ tangible and $70 \%$ intangible assets.

These facts are supported by data in Table 2.1, which shows that market value does not represent all the company's assets. There is a 50\% hidden value, which indicates the performance of knowledge, one of the intangible assets which cannot be assessed by the financial statement. Lev \& Sougiannis (1996) and Amir \& Lev (1996) also stated that tangible assets had valuerelevance degradation, especially in industries dominated by the knowledgeintensive and innovative organization (Syaipudin and Nauli, 2011).

There is an urgency to find a method of intangible asset recognition for more reliable financial statement for decision making. This urgency encourages the study of intangible assets measurement, which at the past considered as an impossible thing. The main problem is the impossibility to measure social phenomena with scientific accuracy (Syeiby, 2010) and the absence of the universal rule of for intangible assets measurement, primarily intellectual capital (Zambon, 2004 in Clarke et al., 2010). It is not easy to do this. Syeiby (2010) had classified proper and accurate methods of IC measurement from studies from all over the world based on Luthy (1998) and Williams' (2000) approachment into four categories: 1) Direct Intellectual Capital methods (DIC); 2) Market Capitalization Methods (MCM), 3) Return on Assets methods (ROA), 4) Scorecard Methods (SC)

Intangible assets in the form of knowledge are known as intellectual capital (IC). Sawarjuwono (2003) said, “... we can define intellectual capital operationally as intellectual material that has been formalized, captured, and leveraged to produce a higher-valued asset". Bontis et al. (2000) in Ulum (2008) also mentioned that 
generally IC consists of three primary constructs: human capital (individual knowledge stock represented by the employees), structural capital (all nonhuman storehouses of knowledge in the organization), and customer capital (marketing channels and customers relationship in business process).

The new trend about IC in the global economy did not make all economy aspects affected. Whiting and Woodcock (2011) stated in the Global Industry Classification Standard (GICS) that there was industry classification into high-technology and low-technology industry. The hightechnology company was regarded as highIC intensive where IC is a primary for its business. Low-technology industry was regarded as low-IC intensive, where IC is not essential (see Table 2.2). GICS was used as the base for sampling to get more reliable results in the research model, so it was suitable for the writer's conviction. These tests were to make sure about previous studies of IC's effect on the company's performance in general.

\section{IC and Profit}

The Committee of Sponsoring Organizations of the Treadway Commission (COSO) in Enterprise Risk Management (ERM) Framework (2004) stated that the company has strategic and operations purposes. Strategic purpose is a target for achieving the company's missions. Operations purpose is based on the effectiveness and efficiency of the company's capital utilization.

Management has to understand the business process and all risks in the company and industry to achieve effective and efficient capital utilization. This knowledge has to be managed to get the maximum result. IC is very vital for this problem. Proper capital utilization can lead the company to get the return more easily.

Hypothesis 1: Intellectual capital has significant effects on ROA simultaneously and partially.

\section{IC, Profit and Market Value}

Previous studies found that many companies had differences between their book value and market value (see Table 2.3). The differences indicated that IC is all of the things (except goods) that helps a company to compete in the market (Chen et al., 2005), and it is regarded as added value. IC can stimulate profits that make the company has a good public reputation. There are three groups of a factor that affect market value; (1) fundamental factors; the combination of earning base (e.g., EPS) and multiple valuations, (2) technical factors, and (3) market sentiment. Increase in profit is also a fundamental factor in market value.

Hypothesis 2: Intellectual capital has a significant effect on market value through ROA

\section{Research Design}

\section{Samples}

This research used purposive sampling from the population. The population consisted of financial statements from high-IC intensive industries (by GICS) and listed in Indonesia stock exchange. These reports provided data for VAIC and ROA calculation for published financial statements in 2014. It all sums up to 215 companies that come from consumer goods industries; property, real estate, and building construction; infrastructure, utilities and transportation; finance; and trade, services, and investment industries. 


\section{Measurement}

This study used companies' intellectual capital indicated by Value Added Intellectual Capital (VAIC); summation of capital employed efficiency coefficient (CEE), human capital efficiency coefficient (HCE) and structural capital (SC), VAIC = CEE+HCE+SCE. CEE is value-added and capital employed ratio. Capital employed is the net book value of the company's assets. CEE calculation formula: $C E E$ = Value Added / Capital Employed. HCE is the ratio of value-added and the company's human capital with employee remuneration as a proxy (Sveiby, 1997).

Company's human capital is total value divided by total salary and wage (Pulic, 1998). HCE calculation formula: HCE $=$ Value Added $/$ Human Capital. SCE is the difference between value-added with human capital. It makes SCE's calculation is different from CEE and HCE because SC and $\mathrm{HC}$ are inversely proportional (Pulic, 1998). The relationship is shown by the following equation: $S C E=($ Value Added Human Capital) / Value Added

Company's leverage is the control variable that represented by debt-to-equity (DER) ratio. Profitability level is the intervening variable that represents financial performance with Return on Assets (ROA) as the indicator. Market value is the dependent variable that shows shareholders' assessment of the company with Price-to-Book Value (PBV) as the indicator.

\section{Empirical Models}

Path analysis with an intervening variable is used as the model. Based on the hypotheses, there are two equations tested in this study

$\mathrm{ROA}=\alpha+\mathrm{PYX} 1 \mathrm{VAIC}+\mathrm{PYX} 2 \mathrm{LEV}+\varepsilon 1$

$\mathrm{PBV}=\alpha+\mathrm{PZY}(\alpha+\mathrm{PYX} \mathrm{ROA}+\varepsilon 1)+\varepsilon 2$ $\alpha=$ constant. PYX1 $=$ multiple regression coefficients of independent variable $\mathrm{X} 1$ to dependent variable $\mathrm{Y}$ if independent variable $\mathrm{X} 2$ were constant. $\mathrm{PYX} 2=$ multiple regression coefficients of independent variable $\mathrm{X} 2$ to dependent variable $\mathrm{Y}$ if independent variable $\mathrm{X} 1$ were constant. $\mathrm{PZY}=$ regression coefficient of intervening variable to dependent variable $\mathrm{Z}$, if the independent variable had to pass the intervening and assumed as constant. $\varepsilon 1$ $=$ other variables that affect ROA. $\varepsilon 2=$ other variables that affect PBV

\section{Result}

To test a model with intervening variable, regression model separation into substructures should be done. In this study, the model substructure was divided into two. The first substructure would test the relationship between leverage-controlledVAIC and ROA, and the second would test the ROA and PBV relationship. The results could be combined for determining VAIC to $\mathrm{PBV}$ through ROA relationship.

Before the regression test, a model must fulfill some classic assumption test. The first substructure, which used crosssection data and had more than one independent variable, needs three classic assumption tests; normality, multicollinearity, and heteroscedasticity. The second substructure, which used crosssection data and had one independent variable, only needs normality and heteroscedasticity test. Both substructures passed all the tests so that the regression test could be done. $\mathrm{R}^{2}$ value of the first substructure is 0.223729 , and it means VAIC and leverage's ability to explain the variance of ROA equals to $22.37 \%$. $\mathrm{R}^{2}$ value of the second substructure is 0.147530 , and it means ROA's ability to explain the variance of PBV equals to $14.75 \%$. 
The combination of both substructures would create the effect explained in Diagram 5.1, which shows the influence of VAIC to ROA and ROA to PBV by accumulating other factors as epsilon. The equation for the regression model is formed by processed data by Eviews 8 software. $\mathrm{Y}=0.021605+$ $0.008695 \mathrm{X} 1-0.005811 \mathrm{X} 2+\varepsilon 1 . \mathrm{Z}=$ $1.365441+9.240111 \mathrm{Y}+\varepsilon 2$. Hypotheses that need $\mathrm{F}$ test to determine the simultaneous effect as prove IC has a significant effect on ROA simultaneously. IC has a significant effect on market value through ROA.

F-calculation from regression result was compared to F-table to determine the significance. The first substructure has Fcalculation $=29.25338$ and 35.30462 for the second substructure. From the table Ftable $=2.65$. Ho1 and Ho2 were rejected because both F-calculation is larger than 2.65. IC had significant effect simultaneously to ROA, and ROA had significant effect simultaneously to market value. It was also supported by 0.000 value for Prob. Number (in the appendix) of all variables (smaller than $\alpha$ ) so it could be concluded that every variable affected the dependent variables significantly. Hypotheses that need t-test to determine the partial effect as prove: IC has a significant effect on ROA partially. t-calculation from regression result was compared to t-table to determine the significance. First substructure had t-calculation $=5.383283$, larger than the $\mathrm{t}$-table $=1.971660843$. Hol was rejected. IC had significant effect partially to ROA. It was also supported by 0.000 value for Prob. Number of VAIC (smaller $\alpha$ ) so it could be concluded that all variables significantly affected its dependent variables.

Data results in this study proved that the relationship of a company's IC with market value is stronger when it was given ROA as an intervening variable. The direct relationship had only $1.97 \%$ value, but an indirect relationship through ROA could increase the value (11.08\% to $13.05 \%)$. IC and ROA relationship was represented in $22.7 \%$ value directly. $\mathrm{F}$ test and t-test also showed that IC with ROA and the company's market value relationship were significant; simultaneously and partially. This conclusion is consistent with some previous studies like Cheng et al. (2005), Ulum et al. (2008) and Clarke (2011) but inconsistent with Solikhah et al. (2010).

Different results are common because most previous IC studies used crosssectional time-series observation for an industry. This study was more focused on the IC relationship in many industry sectors in the same year. Besides the different observed data types, this study also regarded IC as a simultaneous combination of three dimensions of the company's intellectual capital, where every industry has a different composition in needs of IC for each business.

In 2014 (the observation year), IC composition of companies was still dominated by human capital, more than structural capital and capital employed. It showed that companies have already owned good intellectual capital from human resource, but the application was not so maximum that made that human capital had not been able to increase companies' value of structural capital and capital employed.

The regression numbers were not an absolute value that happened in all industrial sectors. Statistical tests on industries would produce different results because each industry has different characteristic that makes IC's role isn't the same in all business process. There are industries that have high IC value because of human resource's high competence when 
other industries have advanced technology that also causes high IC value. The same IC value does not always indicate the same dimension composition of IC.

The average composition of IC's dimension showed that human capital dimension was the largest dimension. Infrastructure, utility, and transportation sector had the highest human capital average with 6.82 value, followed by property and real estate industries with 5.14 value. These data were supported by the government's development program in infrastructure. The rapid development made the needs of high-quality human capital increase. For structural capital dimension, trading and service industry had the highest average value (0.83) and consumer goods industry had the highest average value for the capital employed dimension (0.53).

\section{Conclusion}

Statistical tests and analysis on data of 215 companies from diverse sectoral industries in IDX with high-IC intensive produced some conclusions. First, IC could give a significant effect on the company's ROA directly, simultaneously (with leverage), and partially. It fulfilled the initial guess; adequate intellectual capital would encourage efficient assets usage, tangible and intangible so that it would increase the company's ROA. IC could also give significant indirect effect to market value through ROA. This indirect relationship was even better than the direct relationship. It was explained by so many factors that could affect the dynamic market value. It is not surprising that many studies concluded that independent variables to market value relationship are not significant because there were many factors not included in the model.
The next studies are expected to be able to create a more suitable research model that makes an image of every variable that represents the company's performance could be recorded better and has fewer uncontrollable factors. The research model can be also developed by looking for more proxy in measurement because the results of this study are not significant enough. Trial and error in the IC study are still needed because there is still no global rules for IC, included the basics like exact measurement method.

\section{References}

Bontis, Nick. 1998. Intellectual Capital: An Exploratory Study That Develops Measures and Models. Management Decision Journal, volume 36(2), 6376.

Bontis, Nick; W.C.C. Keow; and S. Richardson. 2000. Intellectual Capital and Business Performance in Malaysian Industries. Journal of Intellectual Capital 1:85-100.

Chang, Shu-Lien. 2007. Valuing Intellectual Capital and Firms' Performance: Modifying Value Added Intellectual Coefficient (VAIC ${ }^{\text {TM) }}$ in Taiwan IT industry. Disertasi Golden Gate University, California.

Chen, Ming-Chin; S.J. Cheng; and Y. Hwang. 2005. An Empirical Investigation of The Relationship Between Intellectual Capital and Firm's Market Value and Financial Performance. Journal of Intellectual Capital 6:159-176.

Clarke, Martin; D. Seng; and R. Whiting. 2011. Intellectual Capital and Firm Performance in Australia. Journal of Intellectual Capital 12: 505-530 
Dolorosa, G. Natalia. 2014. Pertumbuhan IHSG 2014 Pecah Rekor. Available online at: http://bisnis.com/market/read/2014 1230/7/386858/pertumbuhan-ihsg2014-pecah-rekor (access at $19 \mathrm{Mei}$ 2015)

Fiedler, et al. The Influence of Constraints on Organizations: Summary of Contingency Theory. Available online at: http://www.valuebasedmanagement .net/methods_contingency theory.h tml (diakses 24 Juni 2015)

Ghasemi A, dan Zahediasl S. 2012. Normality Tests for Statistical Analysis: A Guide for NonStatisticians. Int $\mathbf{J}$ Endocrinol Metab. 2012;10(2):486-9. DOI: 10.5812/ijem.3505. Available online at http://www.ncbi.nlm.nih.gov/pmc/a rticles/PMC3693611/ (access at 21 Juni 2015)

Gitman, L. J., Zutter, C. J. 2012. Principle of Managerial Finance. Edinburg: Pearson Education.

Harper, David. 2008. Forces That Move Stock Prices. Available online at: http://www.investopedia.com/articl es/basics/04/100804.asp (access at 15 Mei 2015)

Husnan, Suad (2001). Manajemen Keuangan Teori dan Penerapan (Keputusan Jangka Pendek), Buku 2 Edisi 4 Cetakan Pertama. Yogyakarta : BPFE.

Kourdi, Jeremy. 2009. 100 Great Business Ideas: from Leading Companies Around the World. London: Marshall Cavendish International (Asia) Pte Ltd.
Portela de Lima Rodrigues, L. Maria; L. Oliveira and R. Craig. 2008. Applying Voluntary Disclosure Theories to Intangibles Reporting: Evidence from the Portuguese Stock Market. Available at SSRN: http://ssrn.com/abstract $=825764$ or http://dx.doi.org/10.2139/ssrn.8257 $\underline{64}$

Pulic, Anne. 2000. VAICTM- An Accounting Tool For ICManagement. Graz: Austrian Intellectual Capital Research Center, University Of Graz.

Pulic, Anne. 2008. The Principles of Intellectual Capital Efficiency - A Brief Description. Available online at: $\quad$ http://www.cikhr.com/data/principles_2008.pdf (access at 18 Mei 2015)

Pusat Kebijakan Pendapatan Negara Badan Kebijakan Fiskal. ASEAN FREE TRADE AREA (AFTA). Available online at: http://www.tarif.depkeu.go.id/Othe rs/?hi=AFTA (access 19 Mei 2015)

Research and Development Division of Indonesia Stock Exchange. 2014. Fact Book 2014. Available online at:

http://www.idx.co.id/Portals/0/Stati cData/Publication/FactBook/FileD ownload/20140911_FB-2014.pdf (access at 9 April 2015)

. 2014. IDX STATISTICS 2014. Available online at: http://www.idx.co.id/Portals/0/Stati cData/Publication/Statistic/Yearly/I DX Annually_2014.pdf (access at 19 Mei 2015)

Riduwan; dan Kuncoro. 2012. Cara Menggunakan dan Memakai Path Analysis. Bandung: Alfabeta. 
Sangkala. 2006. Intellectual Capital Management: Strategi Baru Membangun Daya Saing Perusahaan. Jakarta: YAPENSI. . 2007. Knowledge Management. Jakarta: Raja Grafindo Persada.

Sawarjuwono, Tjiptohadi; dan A. P. Kadir. 2003. Intellectual Capital: Perlakuan, Pengukuran dan Pelaporan (Sebuah Library Research). Jurnal Akuntansi \& Keuangan 5: $35-57$.

Sekaran, Uma. 2003. Research Methods for Business: A Skill Building Approach, fourth edition. New York: John Wiley \& Sons, Inc.

Solikhah, Badingatus dkk. 2010. Implikasi Intellectual Capital terhadap Financial Performance, Growth dan Market Value. Presented at Simposium Nasional Akuntansi XIII, Purwokerto, 2010.

Standard \& Poor's Indices. 2008. Global Industry Classification Standard Methodology. Available online at: http://www.spindices.com/docume nts/index-policies/methodologygics.pdf (access 21 April 2015)

Sugiyono. 2010. Statistika Untuk Penelitian. Bandung: CV Alfabeta.

Sveiby, Karl-Erik. 2000. A Brief History of The ICM Movement. Available online at: http://www.sveiby.com/articles/icm

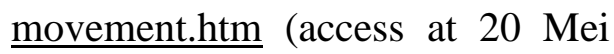
2015)

. 2010. Methods for Measuring Intangible Assets. Available online at:

http://www.sveiby.com/articles/Int angibleMethods.htm (access at 12 April 2015)
Syaipudin, Usep dan P. Nauli. 2011. Analisis Value Relevance Pengungkapan Informasi Intellectual Capital (IC) Perusahaan. Universitas Lampung's Journal.

Ulum, Ihyaul; I. Ghozali; dan A. Chariri. 2008. Intellectual Capital dan Kinerja Keuangan Perusahaan; Suatu Analisis dengan Pendekatan Partial Least Squares.

Whiting, Rosalind H.; and J. Woodcock. 2011. Firm Characteristics and Intellectual Capital Disclosure by Australian Companies. Journal of Human Resource Costing \& Accounting 15: 10 